\title{
Club Cell
}

National Cancer Institute

\section{Source}

National Cancer Institute. Club Cell. NCI Thesaurus. Code C13143.

A rounded, club-shaped, nonciliated cell found in between ciliated cells in the epithelium of respiratory and terminal bronchioles. It has a secretory function. 